\title{
ORIGINAL ARTICLE \\ Bats in tea plantations in Sri Lanka: Species richness and distribution
}

\author{
Tharaka Kusuminda ${ }^{1,{ }^{*}}$, Amani Mannakkara ${ }^{1}$, Bruce D. Patterson ${ }^{2}$, Wipula B. Yapa ${ }^{3}$
}

\author{
${ }^{1}$ Department of Agricultual \\ Biology, Faculty of Agriculture, \\ University of Ruhuna, \\ Kamburupitiya, Sri Lanka. \\ ${ }^{2}$ Integrative Research Center, \\ Field Museum of Natural \\ History, Chicago, Illinois, USA. \\ ${ }^{3}$ Department of Zoology and \\ Environment Sciences, Faculty \\ of Science, University of \\ Colombo, Sri Lanka. \\ *Corresponding author email: \\ t.kusuminda@gmail.com \\ DOI: https://doi.org/10.14709/ \\ BarbJ.11.1.2018.12
}

Keywords: Agro-ecosystem, elevation, insectivorous bats, reproductive ecology, tea

received: August, 6th 2018 accepted: December, 31st 2018

\begin{abstract}
Due to the exponential growth of human population, natural forests are being steadily replaced by areas devoted to agriculture. It is estimated that forty percent of our planet's terrestrial area is allocated to agriculture, causing devastating damage to wildlife. However, on the positive side, the diverse nature of agro-ecosystems offers opportunities for landscape-level approaches to biodiversity conservation. Furthermore, heterogeneous agroecosystems are also known to support rich biological diversity, including bats. Insectivorous bats play a significant role in suppressing insect pests in agro-ecosystems all over the world. Bat insectivory in agricultural landscapes reduces harvest losses and, indirectly, pesticide use, thereby contributing to the production of healthier foods for human consumption. Hence, it is important to understand how insectivorous bats are using different agro-ecosystems. The tea industry contributes significantly to net foreign exchange in the Sri Lankan economy. The diversity of bats exploiting six tea plantations that represent the major tea-growing regions in Sri Lanka was surveyed for one year. We recorded six families and twelve species of bats, eight of which were insectivores. Rhinolophus rouxii was the most commonly recorded species, and was recorded at higher elevations than it has been previously recorded. Similarly, Miniopterus fuliginosus was recorded at Idulgashinna (1590 m), a new maximum elevational record for the species in Sri Lanka. Roosts of seven bat species were documented in the vicinity of each plantation and we provide new breeding observations of three bat species. This study is the first to record four pteropodid bat species in a single tea plantation. This study offers a foundation for future bat studies in the understudied tropical agricultural system of tea plantations.
\end{abstract}

\section{INTRODUCTION}

Bats (Order Chiroptera) include 1386 extant species (Burgin et al. 2018) and are unique among mammals in their evolution of powered flight (Voigt \& Kingston 2016). Although many bat species feed on invertebrates (Kunz et al. 2011), the diversity of bat feeding guilds is extraordinary. According to Maas et al. (2016), include the vertebratefeeding guild (including fish and blood-feeding bats), an omnivorous guild (feeding on both plant and animal matters), the fruit/plant feeding guild (including leaf, flower and bark feeding bats), and the nectar/pollen feeding guild. Here, we treat the last two guilds as the plant-feeding guild. Bats range over the Neotropics (South and Central America), Paleotropics (Africa, Asia and Oceania), Nearctic (North America), and Palaearctic (Northern Eurasia). Some species of vespertilionid bats are known to spend the summer at high latitudes in both hemispheres, and a few bat species are even found north of the Arctic Circle (Altringham 2011). Therefore bats are an ecologically diverse order.

Sri Lanka is a tropical island $\left(65,610 \mathrm{~km}^{2}\right.$ in area) located near the Indian subcontinent (Survey Department of Sri Lanka 2007). Thirty species of bats representing 8 families have been recorded on Sri Lanka, including representatives of Pteropodidae, Rhinolophidae, Hipposideridae, Megadermatidae, Emballonuridae, Vespertilionidae, Miniopteridae and Molossidae (Teeling et al. 2016, Yapa 2017). None of the bat species recorded from Sri Lanka are considered as threatened under the IUCN Red List (IUCN 2018). According to the last national assessment of conservation status, ten species are Threatened and two are Data Deficient (Ministry of Environment 2012).

Studies in tropical ecosystems demonstrate the importance of bats as predators in suppressing arthropod abundance and their herbivory (Kalka et al. 2008, Maas et al. 2016). Biological suppression of arthropod pests is also a key ecosystem service that bats provide to agriculture (Lee \& McCracken 2005, Cleveland et al. 2006, Wanger et al. 2014, Puig-Montserrat et al. 2015). Although bats provide substantial services to people and ecosystem functioning, globally $15 \%$ of bat species are threatened (Critically Endangered, Endangered and Vulnerable), 7\% are Near Threatened, and nearly $18 \%$ are Data Deficient (Voigt \& Kingston 2016). Several anthropogenic activities, including deforestation and land conversion for agricultural use, greatly threaten bat diversity (Racey \& Entwistle 2003, 
Williams-Guillén et al. 2016, Ceballos et al. 2017). Forty percent of our planet's terrestrial areas are covered by agricultural areas, and the area devoted to agriculture is expected to grow with increasing human population growth (Defries et al. 2010). However, the ubiquity of agriculture means that agricultural areas offer opportunities for landscape-level approaches to biodiversity conservation (Vandermeer \& Perfecto 2007). Several studies have shown that diverse agricultural habitats can maintain high species richness of bats in disturbed forested landscapes (Furey et al. 2010, Harvey \& González Villalobos 2007, Wordley et al. 2018). The species richness of bats in agricultural habitats is highly associated with landscape and management variables, including management intensification (Mendenhall et al. 2014), distance to large forest areas (Estrada et al. 1993), distance to forest fragments and forest edges (Wordley et al. 2015) and distance to water sources (Wordley et al. 2015).

Tea (Camellia sinensis) is an economic crop which is widespread in many tropical and subtropical countries. It is one of the major agricultural crops in Sri Lanka, which is the world's fourth largest tea producer. As the leading economic crop in Sri Lanka, tea accounts for $0.8 \%$ of GDP, contributing 75 billion Rupees (US\$ 0.46 billion) to the economy of Sri Lanka in 2015 (Central Bank of Sri Lanka 2017). Tea plantations cover 203,000 hectares and are found in fourteen national districts, in three elevational regions, up country, mid country and low country (Watson \& Zoysa 2008, Central Bank of Sri Lanka 2017). Despite the important role of bats in suppressing insect pests and as bio-indicators of environmental changes (Jones et al. 2009), only one study exists (Wordley et al. 2018) on the diversity of bats in tea plantations, and none have been conducted in Sri Lanka. We carried out a detailed study to assess the diversity of bats in tea plantations in Sri Lanka as a step towards evaluating their insect pest control services.

\section{MATERIALS AND METHODS}

\section{Study Site}

Six tea plantations representing major tea growing regions in Sri Lanka were selected (Fig. 1) as follows; small holder tea plantation at Thawalama $\left(06^{\circ} 22^{\prime} 10.5^{\prime \prime} \mathrm{N}\right.$ and $080^{\circ} 19^{\prime} 27.9^{\prime \prime} \mathrm{E}, 36 \mathrm{~m}$ ) in low country wet zone; large scale tea plantation at Idulgashinna $\left(06^{\circ} 46^{\prime} 36.4^{\prime \prime} \mathrm{N}\right.$ and $080^{\circ}$ $53^{\prime} 26.1^{\prime \prime} \mathrm{E}, 1590 \mathrm{~m}$ ) in up country intermediate zone; large scale tea plantation at Udupussellawa $\left(06^{\circ} 58^{\prime} 08.1^{\prime \prime} \mathrm{N}\right.$ and $080^{\circ} 54^{\prime} 05.1^{\prime \prime} \mathrm{E}, 1408 \mathrm{~m}$ ) in up country intermediate zone; large scale tea plantation at Radella $\left(06^{\circ} 55^{\prime} 47.4^{\prime \prime} \mathrm{N}\right.$ and $080^{\circ} 43^{\prime} 37.5^{\prime \prime} \mathrm{E}, 1427 \mathrm{~m}$ ) in up country wet zone; large scale tea plantation at Yatideriya $\left(07^{\circ} 07^{\prime} 40.6^{\prime \prime} \mathrm{N}\right.$ and $080^{\circ} 22^{\prime}$ $05.9^{\prime \prime} \mathrm{E}, 370 \mathrm{~m}$ ) in mid country wet zone and large scale tea plantation at Maskeliya ( $06^{\circ} 52^{\prime} 17.7^{\prime \prime} \mathrm{N}$ and $080^{\circ} 31^{\prime} 53.7^{\prime \prime} \mathrm{E}$, $1082 \mathrm{~m}$ ) in up country wet zone (Watson \& Zoysa 2008). Tea plantations in Sri Lanka are essentially characterized by monocultures of tea bushes (Camellia sinensis) around 70 $\mathrm{cm}$ height with medium and high shade trees (shade level refers to the height and size of the canopy). While Calliandra calothrysus, Erythrina lithosperma and Gliricidia sepium are recommended as the medium shade trees, Grevillea robusta and Falcataria moluccana are recommended as the large shade trees (Ekanayake 2008). During the eight-month study

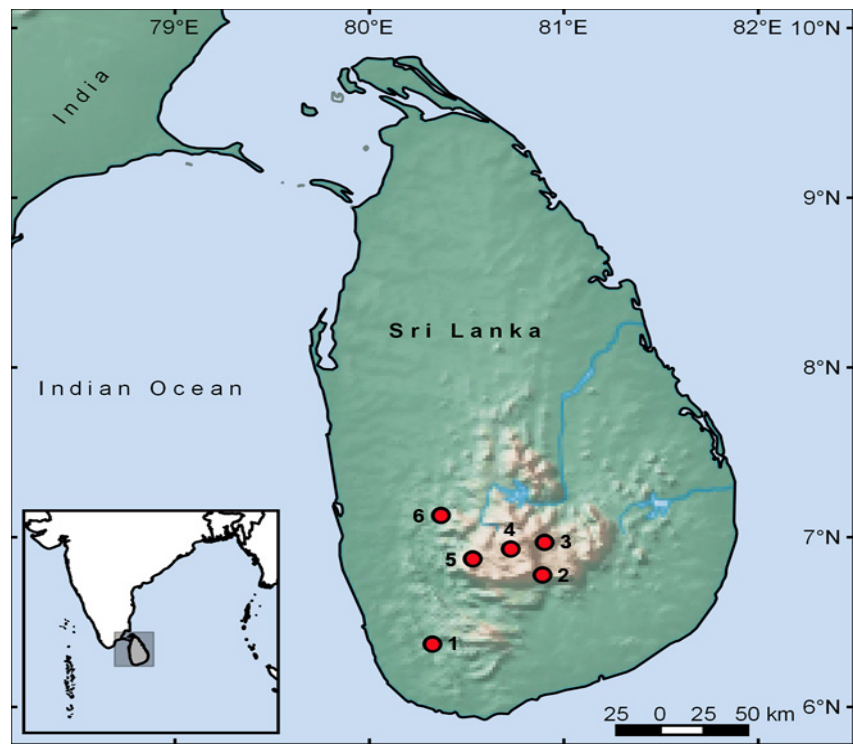

Fig. 1 - Map of the sampled tea plantations. 1: Thawalama, 2: Idulgashinna, 3: Udupussellawa, 4: Radella, 5: Yatideriya, 6: Maskeliya.

period from September 2016 to December 2017, each site was sampled once every two months to assess the species diversity of bats and monthly to record their reproductive phenology and morphological data. Each sampling session for bats consisted of three nights and morphological data were collected for a single night. In addition, during day time a survey was carried out in the vicinity of sampling sites to record the roosting sites of bats.

\section{Capture of Bats}

Bats were captured on tea plantations and at their roosting sites using mist nets, a harp trap, and a hand net with trapping effort of 864,96 , and 12 trap-hours respectively. Bat roosts both on and adjacent to (within $50 \mathrm{~m}$ of the boundary) the tea plantations were studied. Three $2.5 \times 12 \mathrm{~m}$ mist nets (mesh size $38 \mathrm{~mm}$ ) were stacked vertically to create a 7.5×12 $m$ capture area and the mist net system was kept open from sunset to sunrise in tea plantations and monitored at 10 minute intervals. A two-bank harp trap with capture area of $1.8 \times 2.4 \mathrm{~m}$ or a single mist net was placed in front of selected roosting sites to capture and identify roosting bats. The harp trap or mist net was left open in front of the roosts until the end of the evening emergence of bats and monitored continuously or every $10 \mathrm{~min}$ respectively. All captured bats were immediately weighed using a spring balance and diagnostic external morphometric measurements were taken using digital calipers following Bates \& Harisson (1997) and Srinivasulu et al. (2010), and then released at the site of capture.

Measurements include: forearm length (FA), head and body length $(H B)$, tail length ( $T L)$, tibia length (TIB), hind foot length (HF), ear length (EL), tragus length ( $T r L)$, tragus width (TrW), metacarpal of third digit (mclli), proximal phalanx of third digit (pplII), intermediate phalanx of third digit (ipIII), metacarpal of fourth digit (mclV), metacarpal of fifth digit $(\mathrm{mcV})$. GPS coordinates of all sampling sites were recorded using Garmin eTrex 20x hand-held GPS receiver. Species identification was confirmed using regional bat keys and field guides (Phillips 1980, Srinivasulu et al. 2010). We classified the age of the bats either as juveniles or adults by 


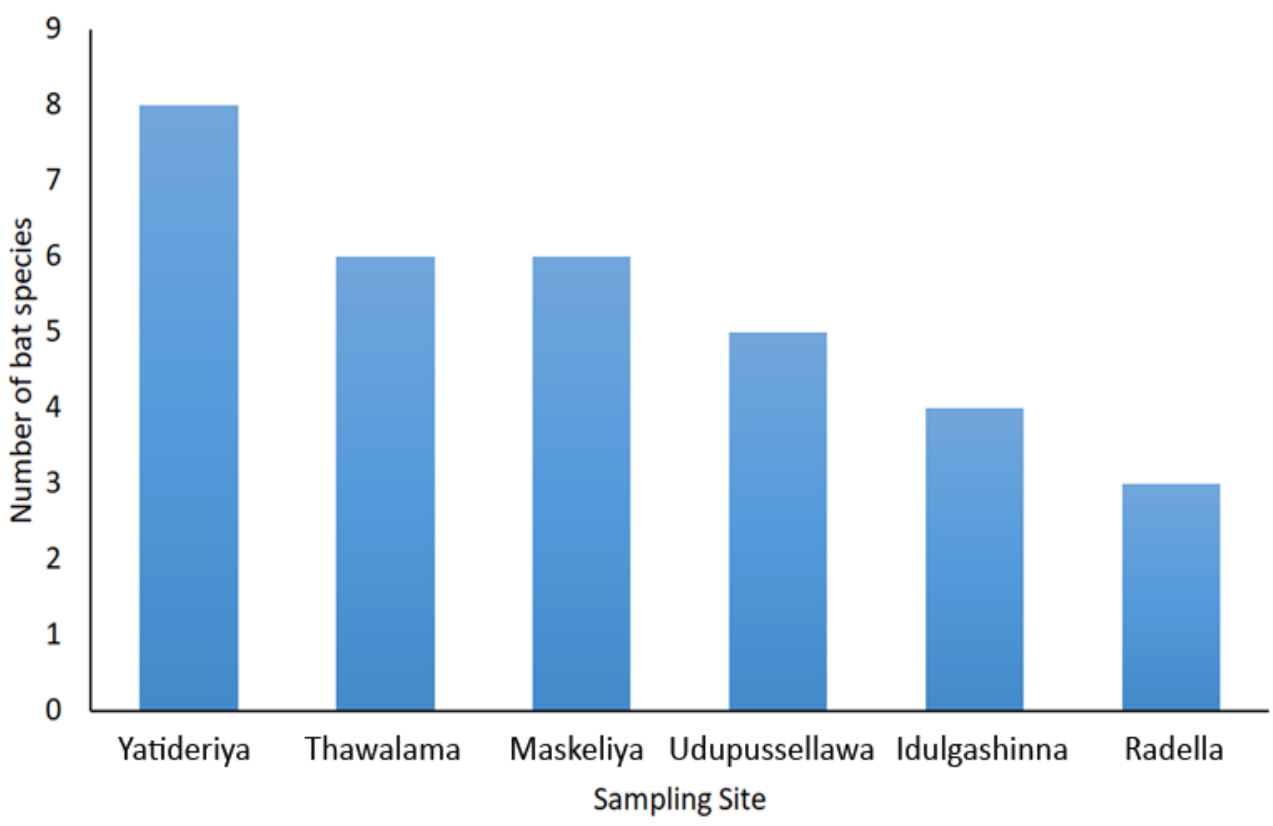

Fig. 2 - Number of bat species recorded from different sampling sites

the presence of cartilaginous epiphyseal plates in the fifth finger bone of juvenile wings and the reproductive status of females by nipple condition and palpating the abdomen (Kunz \& Anthony 1982, Racey 1988). Additional information of foraging behaviors were obtained by direct observation of free-ranging insectivorous bats using red-filtered headlamps and a bat detector (Pettersson M500) during survey sessions. Bats were observed at least $100 \mathrm{~m}$ away from the mist nets to minimize disturbance. Acoustic identifications of insectivorous bats were achieved following Kusuminda et al. (2017) and Kusuminda et al. (2019).

When we captured bats for identification, efforts were made to robustly estimate the population size of the colony. Subsequently, exact counts were obtained as detailed below. Two persons independently counted bats and the average of the counts was used. Clusters of 1 to 50 individuals were counted directly. Clusters of 50 to 200 individuals were photographed using a digital camera, and the bats were later counted from these photographs. Larger colonies (exceeding 200 bats) were counted manually by sitting on opposite sides of the roost entrance as bats emerged from the roost, using red-filtered head lamps. Only two bat roosts had multiple bat species: one was occupied by three species (Hipposideros lankadiva, Hipposideros speoris, and Rhinolophus rouxii) and the other roost was occupied by $H$. speoris and $R$. rouxii. As these bats emerged from the roost, individuals of $H$. lankadiva could be identified by its larger size and wing beat sound. Since the other two species are similar in size and difficult to distinguish in flight, $H$. speoris and $R$. rouxii counts were pooled at these sites. All of the larger colonies recorded by this study occupied roosts with a single small entrance, facilitating censuses. Bats were captured under permission of the Department of Wildlife Conservation of Sri Lanka (WL/3/2/02/2016).

\section{RESULTS AND DISCUSSION}

\section{Species diversity}

Twelve species of bats $(40 \%$ of all species recorded from Sri Lanka) representing six families were captured. Of the total, eight were insectivores and four fed on plant material. Yatideriya had the highest species richness (8 species) whereas Radella (3 species) had the lowest. The plantations averaged 5.3 species of bats per site (Fig. 2). According to the combined results of mist netting and roost surveys, representation of bat families across the six study sites varied. Rhinolophidae and Pteropodidae were present at all six sites, but Vespertilionidae was recorded from four sites, Hipposideridae from three sites, and Megadermatidae and Miniopteridae from only one site (Table 1 ). In terms of mist netting results, species of Rhinolophidae and Pteropodidae were recorded from all sites, Vespertilionidae from four sites, and Hipposideridae and Miniopteridae from two sites (Table 1). The megadermatid was not captured by mist netting. Rhinolophus rouxii, Rousettus leschenaultii, and Cynopterus sphinx were the most frequently recorded species. Pipistrellus ceylonicus, Pipistrellus coromandra, Hipposideros speoris, Miniopterus fuliginosus, and Pteropus giganteus were infrequently caught in mist nets in tea plantations. Three species (Megaderma spasma, Rhinolophus beddomei, and Hipposideros lankadiva) were not captured inside tea plantations but were only recorded at nearby roosts (Table 1). All four bats in the family Pteropodidae known to inhabit Sri Lanka were recorded in tea plantations by this study. In an earlier study, Wordley et al. (2018) recorded eight species of bats (7 insectivores and 1 plant-feeding species) inside tea plantations in India. That study also documented $M$. spasma and $R$. beddomei but not in tea plantations and recorded only a single pteropodid bat $(R$. leschenaultii) in tea plantations. The population size of all recorded bat colonies are documented in Table 2 and external morphometric measurements of captured bats (except $P$. giganteus) are documented in Table 3. 


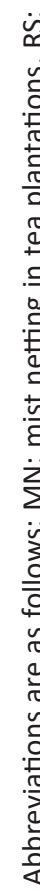

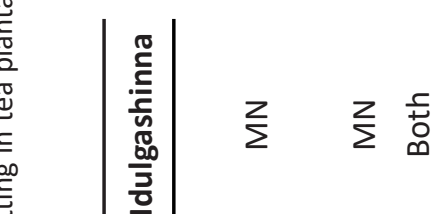

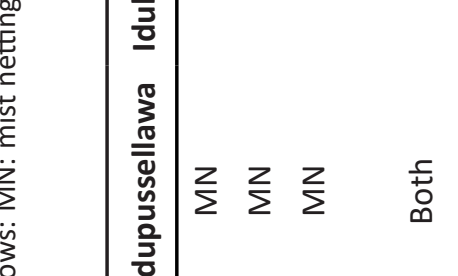

$\frac{\overbrace{}^{2}}{2}$

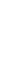

जั.

完

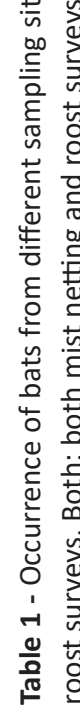

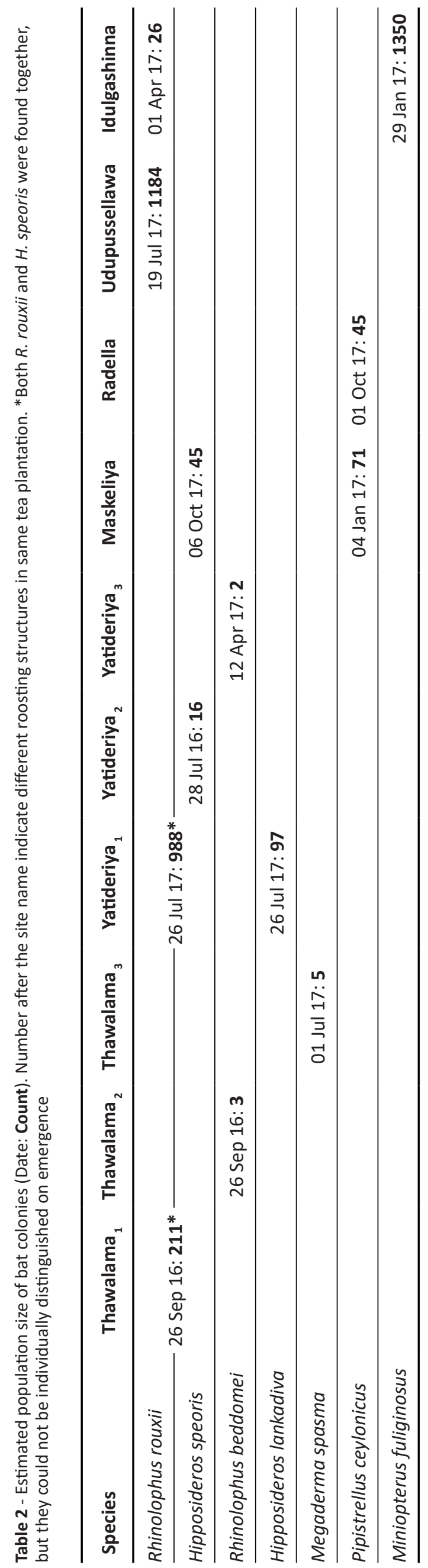


Species Accounts for Insectivorous Bats

\section{Rhinolophus rouxii Temminck, 1835} (Rufous Horseshoe Bat)

Although $R$. rouxii (Fig. 3a) was described in the early 1920's as Sri Lanka's commonest species, subsequent studies (Yapa et al. 1996, Rubsamen et al. 2004) have questioned this assessment, attributing this verdict to the foraging style of forest horseshoe bats (Neuweiler et al. 1987). In the present study, Rufous Horseshoe bat was captured by mist nets at all sampling sites. In addition, this species was found to roost in four structures adjacent to the sampling sites. These included an abandoned plumbago mine at Thawalama, a large rock cave at Yatideriya, an underground tunnel at Udupussellawa, and an underground cave at Idulgashinna. Literature records of this species are mostly confined to the lowlands below 1300 m (Phillips 1980, Yapa \& Ratnavira 2013). Yet we have recorded this species frequently at higher elevations, including Idulgashinna (1590 m), Udupussellawa (1408 m) and Radella (1427 m). We observed these bats feeding on insects very close to the canopy of tea bushes in all sampling sites. Pregnant females were observed in August 2017 from Yatideriya and Thawalama roosts. However, the pregnant and lactating bats were observed in March-April 2017 in the Sthripura tunnel at Udupussellawa. These breeding observations are in agreement with records in Digana (2004). According to Digana (2004), $R$. rouxii have two different breeding seasons in the country, but each roost breeds only once per year. Contrary to previous observations, we observed juveniles hanging on the roof inside the tunnel of Sthripura in December 2017. Those juvenile bats could not fly well at that time, indicating that they had been born a few weeks earlier. This suggests a second breeding season of the species in Sthripura tunnel during the same year. Thus, the present study extends records of distribution, foraging style, and breeding periods of $R$. rouxii in Sri Lanka.

\section{Rhinolophus beddomei K. Andersen, 1905 (Beddome's Horseshoe Bat)}

We observed two roosting structures of $R$. beddomei (Fig. 3b) close to tea plantations in Thawalama and Yatideriya, in an abandoned plumbago mine and a rock crevice respectively. On 12 April 2017, we observed a pup clinging to a mother at Yatideriya site. This observation agrees with the published data about the breeding period of $R$. beddomei (Phillips 1980, Edirisinghe et al. 2016). At $370 \mathrm{~m}$, the record from site Yatideriya constitute the third highest elevation record of this species, after Rattota (462 $\mathrm{m}$ ) and Medamahanuwara (1077 m) in Sri Lanka (Bates \& Harisson 1997, Phillips 1980, Yapa 2017).

\section{Miniopterus fuliginosus (Hodgson, 1835) (Eastern Long-fingered Bat)}

This species (Fig. 3c) was only recorded from Idulgashinna in this study. It was roosting with $R$. rouxii in an underground cave situated on a steep slope with the entrance well hidden in trees and shrubs. This cave is located at an edge of the tea plantation. According to Phillips (1980), this species has been recorded in Sri Lanka up to $1230 \mathrm{~m}$ elevation, but the roost at Idulgashinna is at $1590 \mathrm{~m}$, making it the

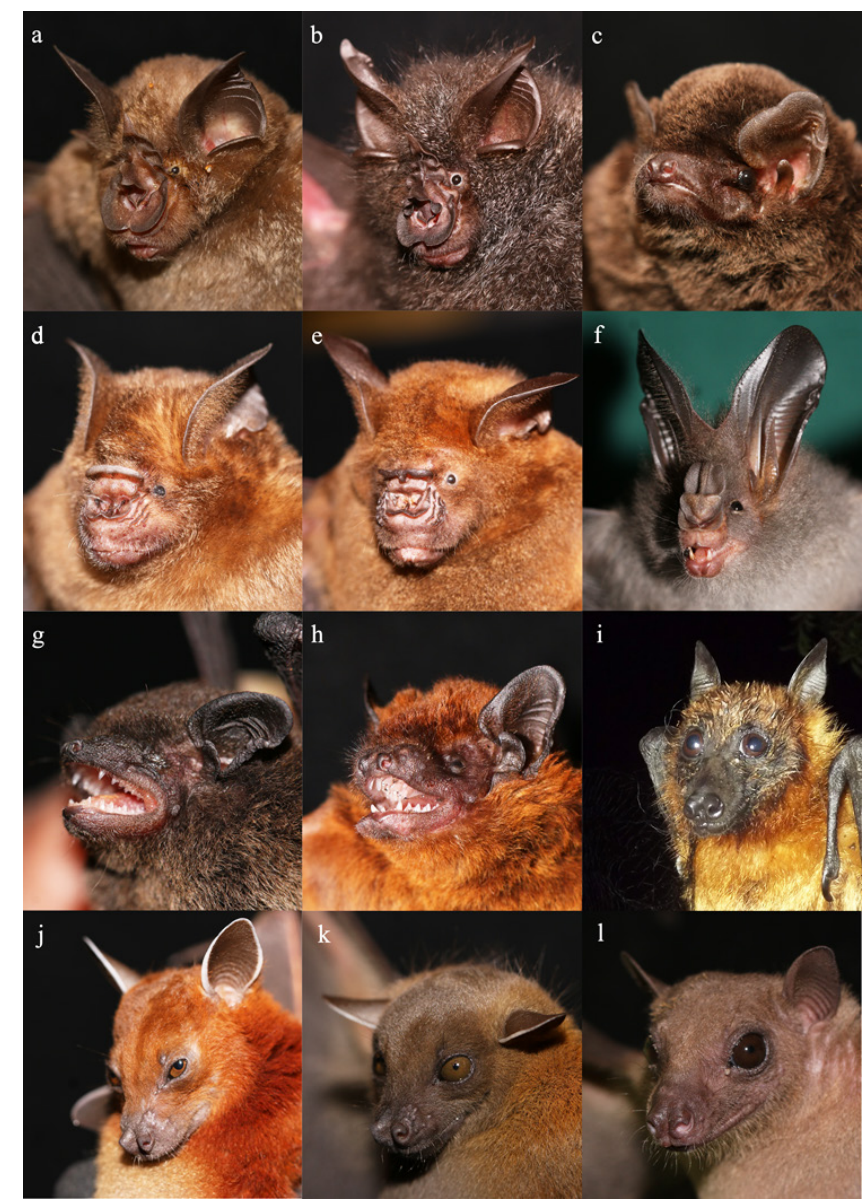

Fig. 3 - Bat species recorded by the study, (a) Rhinolophus rouxii, (b) Rhinolophus beddomei, (c) Miniopterus fuliginosus, (d) Hipposideros speoris, (e) Hipposideros lankadiva, (f) Megaderma spasma, (g) Pipistrellus coromandra, (h) Pipistrellus ceylonicus, (i) Pteropus giganteus, (j) Cynopterus sphinx, (k) Cynopterus brachyotis and (I) Rousettus leschenaultii. Pictures by Tharaka Kusuminda

highest elevational record of this species in Sri Lanka. We observed pregnant bats in July and lactating bats in August 2017, in agreement with the documented breeding period of this bat in Sri Lanka (Digana 2004, Yapa 2017). Digana (2004) recorded that both males and females of this species migrate from Wavulgalge cave to Wavulpane cave (which lie approximately $60 \mathrm{~km}$ apart) for parturition and are absent in Wavulgalge cave during August to December. However, we observed both sexes present in the Idulgashinna cave throughout the year, including lactating females. Digana (2004) documented the distinctive mean temperature (t) and relative humidity $(\mathrm{RH})$ of the parturition chamber (24.20C, 95.1\%) in Wawulpane cave, and suggested that these conditions may be necessary for maternity roosts of this species. But Idulgashinna cave is located at a higher elevation than either Wavulgalge or Wavulpane caves, and its ambient environmental parameters (maximum t: 19.2oC, maximum $\mathrm{RH}$ : $99 \%$ ) resemble the environmental conditions of the Wavulpane cave parturition chamber. This may explain why the population resides all year at Idulgashinna cave without migrating to another maternity cave for parturition. The discovery that Idulgashinna cave is a second known maternity roost for this species in Sri Lanka therefore represents another important finding of this study. 


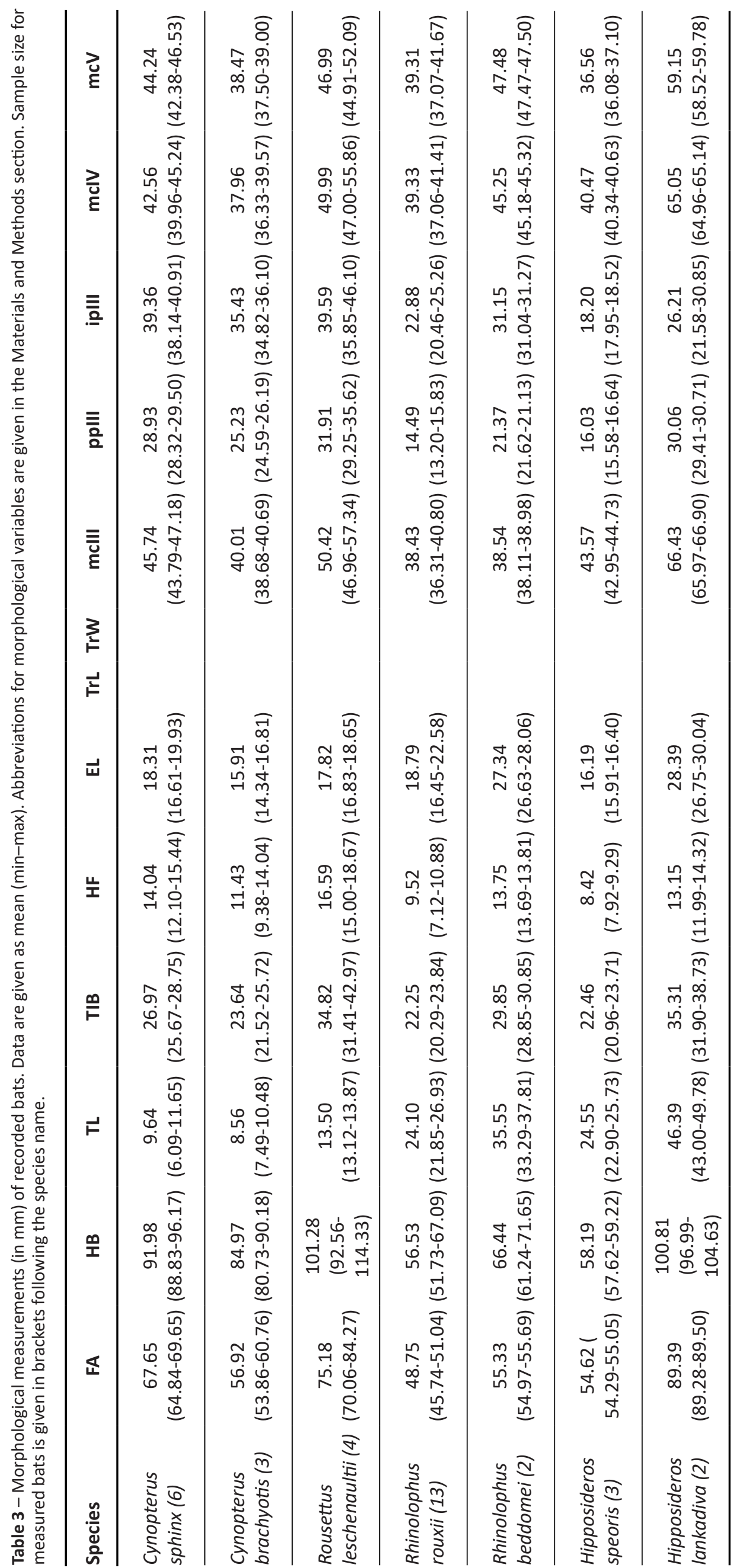




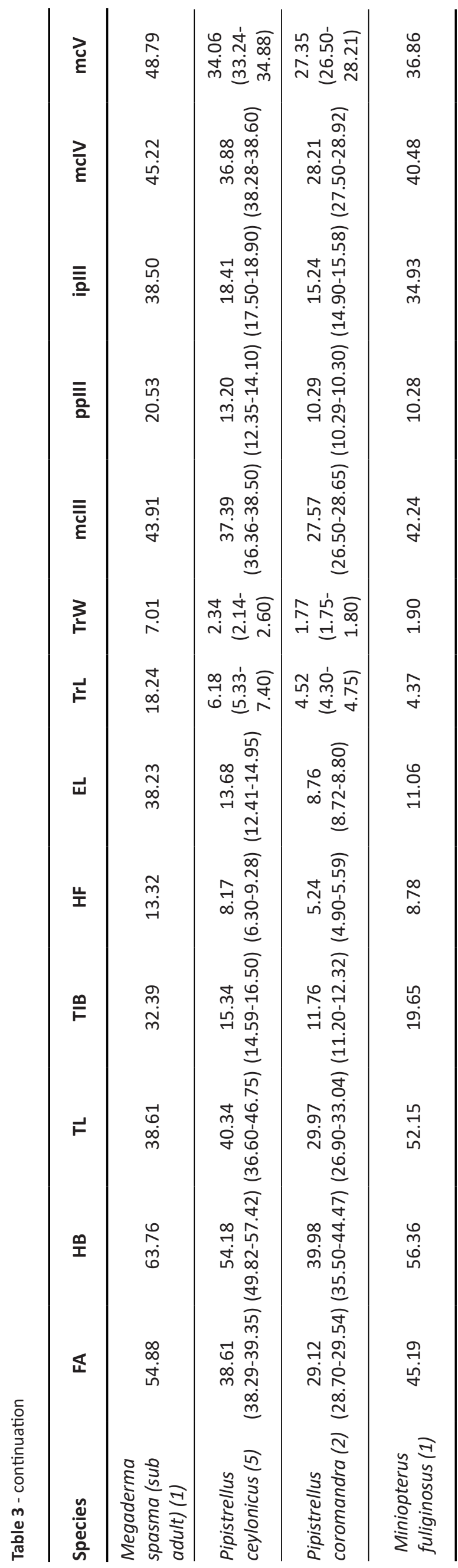

\section{Hipposideros speoris (Schneider, 1800) (Schneider's Leaf-nosed Bat)}

Roosting structures of Schneider's leaf-nosed bat (Fig. 3d) were recorded at Thawalama, Yatideriya, and Maskeliya. The former roost was an abandoned plumbago mine, where $H$. speoris was found roosting with $R$. rouxii. At Yatideriya, we located colonies of $H$. speoris roosting in two different rock caves. At the larger cave, $H$. speoris was found roosting with $H$. lankadiva and $R$. rouxii, but it was the exclusive occupant of the smaller cave. At Maskeliya, a colony of $H$. speoris was found in an abandoned store room. During the study, we observed pregnant females in August 2017 at Yatideriya and mothers with pups in September 2016 and 2017 at Thawalama. These breeding observations are in agreement with Digana (2004). Females of this species normally carry their pups with them during foraging.

\section{Hipposideros lankadiva Kelaart, 1850 (Indian Leaf-nosed Bat)}

This is the largest of the insectivorous bats in Sri Lanka and an uncommon species (Fig. 3e). Recent records were confined to only a few locations. We recorded this species only at the Yatideriya, in a large rock cave where it roosts together with $H$. speoris and $R$. rouxii.

\section{Megaderma spasma (Linnaeus, 1758) (Lesser False Vampire Bat)}

This is a partially carnivorous bat, feeding on larger insects and small vertebrates (Fig. 3f) (Norberg \& Fenton 1988, Nandasena 2012). A colony of $M$. spasma was observed under the roof of an abandoned house near the tea plantation at Thawalama.

\section{Pipistrellus coromandra (Gray, 1838) (Coromandel Pipistrelle)}

This species (Fig. 3g) was recorded at both Yatideriya and Udupussellawa during this study, but no roosting structure for $P$. coromandra was located. An adult female with a pup was caught in a mist net on 31 December 2016 at Yatideriya. On several subsequent visits, we observed a few similarsized bats flying in the evening close to a large decaying tree trunk, which may be their roosting site at Yatideriya. At Udupussellawa, a female bat was caught in a mist net set near a water pool.

\section{Pipistrellus ceylonicus (Kelaart, 1852) (Kelaart's Pipistrelle)}

Kelaart's Pipistrelle (Fig. $3 \mathrm{~h}$ ) is similar in size to $M$. fuliginosus and a common bat in the highlands of Sri Lanka (Phillips 1980). We recorded P. ceylonicus at Maskeliya, Radella, and Udupussellawa sites. At Maskeliya, P. ceylonicus roost under the roof of a plantation building. At Radella, this species was observed in holes and cracks of eight large Falcataria moluccana trees. These trees were established as interim large shade trees in up country tea plantations of Sri Lanka (Ekanayake 2008). Because these trees provide many roosting places, they are important for the conservation of this bat. At Udupussellawa, this species was caught in a mist net. Pregnant bats were observed at Maskeliya in October 
2017 and at Radella in August and October 2017, when hairless pups were observed clinging to their mothers. At Maskeliya, two well grown foeti were observed in October 2017 in a bat which had been killed by a domestic cat. Phillips (1980) observed a female in an advanced stage of pregnancy in September, and Madhavan (1971) described this species as a seasonally monoestrous bat. This evidence of strong seasonality in our breeding records conflicts with Digana's (2004) conclusion that this species shows an aseasonal breeding pattern (breeding throughout the year). With these conflicting observations on $P$. ceylonicus reproduction, a systematic and long-term study of reproductive ecology is needed.

\section{Notes on the family Pteropodidae}

Indian Flying Fox (Pteropus giganteus Brünnich 1782) was observed flying above all six sampling sites, and a single male bat was caught in a mist net at Udupussellawa (Fig. 3i). Leschenault's Rousette (Rousettus leschenaultii Desmarest 1820) and Greater Short-nosed Fruit bat (Cynopterus sphinx Vahl 1797) were also common bats (Fig. 3l \& 3j), each caught at five of six sites. $R$. leschenaultii was not recorded from Udupussellawa nor was C. sphinx from the Radella. We observed a well-furred pup of $R$. leschenaultii with its mother in August 2017 at Thawalama. According to Yapa (2017), this species has two reproductive cycles per year in Sri Lanka, one in April-May and the other in August-September. The early part of the second pregnancy overlaps with the lactation period of the first. Our observation is in agreement with previous breeding records of this species in Sri Lanka (Digana 2004, Yapa 2017). The Lesser Dog-faced Fruit bat (Cynopterus brachyotis Muller 1838) is an uncommon bat we only caught twice (in mist nets at Yatideriya and Udupussellawa) (Fig. 3k). According to Mapatuna et al. (2002), this species was only found in forest habitats in Sri Lanka, but our results indicate that $C$. brachyotis also flies over agricultural habitats, which is in agreement with Tan et al. (1998) and Karuppudurai \& Sripathi (2018). We found that pteropodid bats use tea plantations to find foods growing in shade trees as well as for moving between forest patches.

\section{CONCLUSIONS}

Our study documented the presence of twelve species of bats living in association with tea plantations in Sri Lanka. They represent $40 \%$ of the total bat species in the country. The large areal extent of tea plantations suggests that they could constitute important foraging habitats for various bat species in Sri Lanka. The presence of forest-restricted species such as Rhinolophus rouxii in tea plantations is an important finding of this study. Whether the recorded species utilize tea plantations as their principal or exclusive foraging habitats needs to be assessed by future studies. Most of the bat species identified in the study are insectivorous, but the role of insectivorous bats in pest suppression is not recognised by tea growers. Therefore, quantifying insect consumption by insectivorous bats, especially of pest species, will be an important next step, to highlight the ecological services provided by bats. Tea plantations are open habitats and therefore harp trapping was ineffective. A combination of methods, especially mist netting with passive acoustic surveys, may be more effective to study the bat species exploiting tea plantations: some bats fly high above ground and are difficult to catch, whereas others emit very high frequency echolocation calls and are hard to detect by distant sound recorders. The absence of conflicts between tea planters and fruit bats means that threats to pteropodid bats are minimal in this habitat compared to fruit plantations during foraging bouts of bats. However, roosts of both pteropodid and non-pteropodid bats are situated in highly disturbed environments. Human intrusions to bat roosts, hunting for meat and medicinal purposes, and general persecution are the major threats to all bats roost in tea plantations. Until the public better understands the importance of the ecosystem services provided by bats, existing bat roosting structures must be protected from disturbance.

\section{ACKNOWLEDGEMENTS}

We would like to extend our sincere gratitude to the owners and managers of all sampling sites and their staff for their support of the surveys. We would also like to thank Rajika Gamage and several staff members of Tea Research Institute at Talawakelle, Hanthana, Ratnapura and Passara for helping to find suitable sampling sites. Mathisha Karunarathna, Malinga Pathum, Dilshan Madusanka, Sameera Karunarathna, Krishan Wewalwala, Srinath Amarasinghe, and Kavishka Chathuranga provided their tireless assistance during field work and highly appreciated their effort. Further we would like to thank the Department of Wildlife Conservation for issuing the research permit (WL/3/2/02/2016) and Institute of Biology for issuing the ethical clearance certificate. This work was supported by the National Research Council; under Grant 15-111; and Rufford Foundation under Grant 17065-1. We are also grateful to two anonymous reviewers and the editors for their constructive comments to improve this paper.

\section{REFERENCES}

ALTRINGHAM, J.D. (2011). Bats from evolution to conservation. Oxford university press. New York, USA, $324 \mathrm{pp}$.

BATES, P.J.J. \& HARRISON, D.L. (1997). Bats of the Indian Subcontinent. Harrison Zoological Museum. Kent, UK, $268 \mathrm{pp}$.

BURGIN, C.J., COLELLA, J.P., KAHN, P.L. \& UPHAM, N.S. (2018). How many species of mammals are there? Journal of Mammalogy, 99(1):1-14. https://doi.org/10.1093/ jmammal/gyx147

CEBALLOS, G., EHRLICH, P.R. \& DIRZO, R. (2017). Biological annihilation via the ongoing sixth mass extinction signaled by vertebrate population losses and declines. PNAS, 114(30): 6089-6096. https://doi.org/10.1073/ pnas. 1704949114

CENTRAL BANK OF SRI LANKA. (2017). Economic and social statistics of Sri Lanka. Statistics Department. Central Bank of Sri Lanka, Colombo, Sri Lanka, 186 pp. 
CLEVELAND, C.J., BETKE, M., FEDERICO, P., FRANK, J.F., HALLAM, T.G., HORN, J., LÓPEZ JR, J.D., MCCRACKEN, G.F., MEDELLÍN, R.A., MORENO-VALDEZ, A., SANSONE, C.G., WESTBROOK, J.K. \& KUNZ, T.H. (2006). Economic value of the pest control service provided by Brazilian free-tailed bats in south-central Texas. Frontiers in Ecology and the Environment, 4(5):238-243. https://doi. org/10.1890/1540-9295(2006)004[0238:EVOTPC]2.0. $\mathrm{CO} ; 2$

DEFRIES, R.S., RUDEL, T., URIARTE, M. \& HANSEN, M. (2010). Deforestation driven by urban population growth and agricultural trade in the twenty-first century. Nature geoscience, 3:1-4. https://doi.org/10.1038/ngeo756

DIGANA, P.M.C.B. (2004). Some aspects on ecology and biology of Sri Lankan bats. University of Colombo. Colombo, Sri Lanka.

EDIRISINGHE, W.G.M., DE SILVA, I.M.C., KUSUMINDA, T.G.T., THILINA, M.H.D.K. \& GUNAWARDANA, K.D.S.D. (2016). New breeding data on Rhinolophus beddomei in Sri Lanka: first record of juveniles. Journal of Bat Research and Conservation, 9(1):1-3. https://dx.doi.org/10.14709/ BarbJ.9.1.2016.03

EKANAYAKE, P.B. (2008). Planting and management of shade trees, green manure crops and wind belts. In: Hand Book on Tea. ed.: Tea Research Institute of Sri Lanka. Talawakele, Sri Lanka. p. 86-89.

ESTRADA, A., COATES-ESTRADA, R. \& MERITT, JR. D. (1993). Bat species richness and abundance in tropical rain forest fragments and in agricultural habitats at Los Tuxtlas, Mexico. Ecography, 16(4):309-318.

FUREY, N.M., MACKIE, I.J. \& RACEY, P.A. (2010). Bat diversity in Vietnamese limestone karst areas and the implications of forest degradation. Biodiversity and Conservation, 19(7):1821-1838. https://doi.org/10.1007/s10531-0109806-0

HARVEY, C.A. \& GONZÁLEZ VILLALOBOS, J.A. (2007). Agroforestry systems conserve species-rich but modified assemblages of tropical birds and bats. Biodiversity and Conservation, 16(8):2257-2292. https://doi. org/10.1007/s10531-007-9194-2

IUCN (2018, July 5). The IUCN Red List of Threatened Species. Version 2018-1.

JONES, G., JACOBS, D.S., KUNZ, T.H., WILLIG, M.R. \& RACEY, P.A. (2009). Carpe noctem: the importance of bats as bioindicators. Endangered Species Research, 8(1-2: 93115. https://doi.org/10.3354/esr00182

KALKA, M.B., SMITH, A.R. \& KALKO, E.K.V. (2008). Bats limit arthropods and herbivory in a tropical forest. Science, 320(5872):71. https://doi.org/10.1126/science.1153352
KARUPPUDURAI, T. \& SRIPATHI, K. (2018). Foraging and roosting ecology of the Lesser Dog-faced Fruit Bat Cynopterus brachyotis (Mammalia: Chiroptera: Pteropodidae) in southern India. Journal of Threatened Taxa, 10(9):12163-12172. https://doi.org/10.11609/ jott.3850.10.9.12163-12172

KUNZ, T.H. \& ANTHONY, E.L.P. (1982). Age estimation and post-natal growth in the bat Myotis lucifugus. Journal of Mammalogy, 63(1):23-32. https://doi. org/10.2307/1380667

KUNZ, T.H., DE TORREZ, E.B., BAUER, D., LOBOVA, T. \& FLEMING, T.H. (2011). Ecosystem services provided by bats. Annals of the New YorkAcademy of Sciences, 1223:138. https://doi.org/10.1111/j.1749-6632.2011.06004.x

KUSUMINDA, T.G.T., MANNAKKARA, A., YAPA, W.B. \& PATTERSON, B.D. (2017). Acoustic identification of Kelaart's Pipistrelle Bat (Pipistrellus ceylonicus) in Sri Lanka to effectively monitor its abundance and activity. In: Proceedings of the 22nd International Forestry and Environment Symposium, University of Sri Jayewardenepura, Nugegoda, Sri Lanka, p. 30

KUSUMINDA, T.G.T., MANNAKKARA, A., AMARASINGHE, C.J., KARUNARATHNA, K.A.P.M.K., PATTERSON, B.D. \& YAPA, W.B. (2019). Echolocation call characteristics of rhinolophid bats in Sri Lanka. In Proceedings of the 8th Young Scientists Forum Symposium (Y. S. Liyanaarachchi, ed.), National Science and Technology Commission, Colombo, Sri Lanka, p. 54-58.

LEE, Y.F. \& McCRACKEN, G.F. (2005). Dietary variation of Brazilian free-tailed bats links to migratory populations of pest insects. Journal of Mammalogy, 86(1):67-76. https://doi.org/10.1644/1545-1542(2005)086<0067:DV OBFB $>2.0 . C O ; 2$

MAAS, M., KARP, D.S., BUMRUNGSRI, S., DARRAS, K., GONTHIER, D., HUANG, J.C.C., LINDELL, C.A., MAINE, J.J., MESTRE, L.L., MICHEL, N.L., MORRISON, E.B., PERFECTO, I., PHILPOTT, S.M., SEKERCIOGLU, C.H., SILVA, R.M., TAYLOR, P.J., TSCHARNTKE, T., VAN BAEL, S.A., WHELAN, C.J. \& WILLIAMS-GUILLEN, K. (2016). Bird and bat predation services in tropical forests and agroforestry landscapes. Biological Reviews, 91(4):1080-1101. https://doi.org/10.1111/brv.12211.

MADHAVAN, A. (1971). Breeding habit of the Indian vespertilionid bat, Pipistrellus ceylonicus chrysothrix (Wroughton). Mammalia, 35(2):283-306. https://doi. org/10.1515/mamm.1971.35.2.283

MAPATUNA, Y., GUNASEKARA, M.B., RATNASOORIYA, W.D., GOONESEKERE, N.C.W. \& BATES, P.J.J. (2002). Unravelling the taxonomic status of the genus Cynopterus (Chiropters: Pteropodidae) in Sri Lanka by multivariate morphometrics and mitochondrial DNA sequence analysis. Mammalian Biology, 67(6):321-337. https:// doi.org/10.1078/1616-5047-00049 
MENDENHALL, C.D., KARP, D.S., MEYER, C.F.J., HADLY, E.A. \& DAILY, G.C. (2014). Predicting biodiversity change and averting collapse in agricultural landscapes. Nature, 509:213-217. https://doi.org/10.1038/nature13139

MINISTRY OF ENVIRONMENT. (2012). The National Red List 2012 of Sri Lanka: Conservation Status of the Fauna and Flora. Ministry of Environment. Colombo, Sri Lanka. 452 pp.

NANDASENA, M.R.M.P. (2012). A comparative study of distribution and diet in two sympatric false vampire bat species, Megaderma lyra and Megaderma spasma in Sri Lanka and an investigation of the social behavior of $M$. lyra in natural conditions. University of Colombo. Colombo, Sri Lanka.

NEUWEILER, G., METZNER, W., HEILMANN, U., RUBSAMEN, R., ECKRICH, M. \& COSTA, H.H. (1987). Foraging behaviour and echolocation in the Rufous horseshoe bat (Rhinolophus rouxi) of Sri Lanka. Behavioral Ecology and Sociobiology, 20(1):53-67.

NORBERG, U.M. \& FENTON, M.B. (1988). Carnivorous bats? Biological Journal of the Linnean Society, 33(4):383-394. https://doi.org/10.1111/j.1095-8312.1988.tb00451.x

PHILLIPS, W.W.A. (1980). Manual of the Mammals of Sri Lanka, Part 1: Insectivora and Chiroptera. Wildlife and Nature Protection Society. Colombo, Sri Lanka. 116 pp.

PUIG-MONTSERRAT, X., TORRE, I., LÓPEZ-BAUCELLS, A., GUERRIERI, E., MONTI, M.M., RÀFOLS-GARCÍA, R., FERRER, X., GISBERT, D. \& FLAQUER, C. (2015). Pest control service provided by bats in Mediterranean rice paddies: linking agroecosystems structure to ecological functions. Mammalian Biology, 80:237-245. https://doi. org/10.1016/j.mambio.2015.03.008

RACEY, P.A. (1988). Reproductive assessment in bats. In: Ecological and Behavioral Methods for the Study of Bats. ed.: Smithsonian Institution Press. Washington, USA. p. 31-45.

RACEY, P.A. \& ENTWISTLE, A.C. (2003). Conservation ecology of bats. In: Bat ecology. ed.: University of Chicago Press. Illinois, USA. p. 680-743.

RUBSAMEN, R., ECKRICH, M. \& COSTA, H.H. (2004). Cave dwelling bats in Sri Lanka. Spolia Zeylanica, 41:102-109.

SRINIVASULU, C., RACEY, P.A. \& MISTRY, S. (2010). A key to the bats (Mammalia: Chiroptera) of South Asia. Journal of Threatened Taxa, 2(7):1001-1076. http://dx.doi. org/10.11609/JoTT.o2352.1001-76

SURVEY DEPARTMENT OF SRI LANKA. (2007). The national atlas of Sri Lanka. Survey Department of Sri Lanka. Colombo, Sri Lanka, 243 pp.

TAN, K.H., ZUBAID, A. \& KUNZ, T.H. (1998). Food habits of Cynopterus brachyotis (Muller) (Chiroptera: Pteropodidae) in Peninsular Malaysia. Journal of Tropical Ecology, 14(3):299-307.
TEELING, E.C., JONES, G. \& ROSSITER, S.J. (2016). Phylogeny, genes, and hearing: implications for the evolution of echolocation in bats. In: Bat Bioacoustics. ed.: Springer. New York, p. 25-54.

VANDERMEER, J. \& PERFECTO, I. (2007). The agricultural matrix and a future paradigm for conservation. Conservation Biology, 21(1):274-277. https://doi. org/10.1111/j.1523-1739.2006.00582.x

VOIGT, C.C. \& KINGSTON, T. (2016). Bats in the Anthropocene. In: Bats in the Anthropocene: Conservation of Bats in a Changing World. ed.: Christian C. Voigt \& Tigga Kingstom. Springer International AG, Basel, Switzerland, p. 1-9. https://doi.org/10.1007/978-3-319-25220-9

WANGER, T.C., DARRAS, K., BUMRUNGSRI, S., TSCHARNTKE, T. \& KLEIN, A. (2014). Bat pest control contributes to food security in Thailand. Biological Conservation, 171:220 223. https://doi.org/10.1016/j.biocon.2014.01.030

WATSON, M. \& ZOYSA, A.K.N. (2008). Climatic requirements and soil. In: Hand Book on Tea. ed.: Tea Research Institute of Sri Lanka, Talawakele, Sri Lanka p. 10-15.

WILLIAMS-GUILLÉN, K., OLIMPI, E., MAAS, B., TAYLOR, P.J. \& ARLETTAZ, R. (2016). Bats in the anthropogenic matrix: challenges and opportunities for the conservation of Chiroptera and their ecosystem services in agricultural landscapes. In: Bats in the Anthropocene: Conservation of Bats in a Changing World. ed.: Springer International AG, Basel, Switzerland, p.151-178. https://doi. org/10.1007/978-3-319-25220-9

WORDLEY, C.F.R., SANKARAN, M., MUDAPPA, D. \& ALTRINGHAM, J.D. (2015). Landscape scale habitat suitability modelling of bats in the Western Ghats of India: Bats like something in their tea. Biological Conservation, 191:529-536. https://doi.org/10.1016/j. biocon.2015.08.005

WORDLEY, C.F.R., SANKARAN, M., MUDAPPA, D. \& ALTRINGHAM, J.D. (2018). Heard but not seen: Comparing bat assemblages and study methods in a mosaic landscape in the Western Ghats of India. Ecology and Evolution, 8(8): 3883-3894. https://doi.org/10.1002/ ece 3.3942

YAPA, W.B., DIGANA, P.M.C.B., RANDENIYA, P.V. \& RATNASOORIYA, W.D. (1996). Some observations on the distribution and abundance of the microchiropteran bats in the wet zone of Sri Lanka. Proceedings of the 16th Annual Sessions of the Institute of Biology, Colombo, Sri Lanka, p. 4.

YAPA, A. \& RATNAVIRA, G. (2013). The Mammals of Sri Lanka. Field Ornithology Group of Sri Lanka. Colombo, Sri Lanka, 1012 pp.

YAPA, W.B. (2017). A Field Guide to the Bats of Sri Lanka. Dilmah Ceylon Tea Company PLC. Colombo, Sri Lanka, $141 \mathrm{pp}$. 